\title{
MILK AS A SUBSTITUTE FOR SERUM IN DIAGNOSIS OF TOXOPLASMOSIS IN GOATS
}

\author{
By \\ MARWA M. ATTIA ${ }^{1 *}$, M. F. SAAD ${ }^{2}$, AND AYAH B. ABDEL-SALAM ${ }^{2}$ \\ Departments of Parasitology ${ }^{{ }^{*}}$ and Food Hygiene \& Control ${ }^{2}$, Faculty of Veterinary \\ Medicine, Cairo University, Giza, P.O Box 12211, Egypt \\ ('Correspondence: vetpara@yahoo.com)
}

\begin{abstract}
The present study determined the milk value rather than serum in diagnosis of toxoplasmosis in goats using ELISA and Modified Agglutination Test (MAT). ELISA proved to be more specific and sensitive (92\% \& 85\%), than MAT (90\% \& 80\%) in diagnosis of Anti-T. gondii Antibodies (ATAb) in group of microscopically proved $T$. gondii aborted goats respectively.

There was a direct relationship between the mean ELISA O.D. value and the level of Ab-titer in MAT positive sera. The overall prevalence of infection in 600 serum samples from grazing goats was $22 \%$ and $20 \%$ after examination using ELISA and MAT respectively. It was lower after examination of their milk (20\%) and (18\%) by both techniques respectively. ATAb were significant high in serum $(P<0.05)$ during January, February and March, decreased significantly in April $(P<0.05)$ till August, then significant increased $(P<0.05)$ from September to December using ELISA. In time where ATAb were present by different levels among the whole year in serum, it didn't diagnose in milk from June to September. The infection was high in Egyptian Baladi breed in serum and milk (30\% and 27\%), while the Barki breed was the lowest one $(13.33 \%$ and $12 \%$ ) respectively. High rate of infection (30\% in serum and $27 \%$ in milk) was recorded in goats $>2$ years old, while no ATAb could be detected in goats less than one year old. The highest prevalence of infection $(39.28 \%$ in serum and $37.14 \%$ in milk) was in Qalyoubia, the lowest one $(11.25 \%$ \& $9.58 \%)$ was in Giza governorate. The prevalence of infection was high after examination of serum and milk of goats with previous history of abortion in comparison with the other goats.
\end{abstract}

Keywords: Egypt, Toxoplasma gondii, goat's milk, ELISA, MAT, Zoonosis

\section{Introduction}

Toxoplasmosis is an emerging and reemerging zoonotic disease caused by cat enteric protozoon, T. gondii. The cat (definitive host) can infect all animals, birds, man even dog and cat as intermediate hosts (IMH). The disease transmitted via consumption of contaminated feeding materials (including milk) by oocyst, tachyzoites or bradyzoites of the parasite (Dubey, 2010; Dubey and Jones, 2014). Moreover, toxoplasmosis had also been reported as the second largest cause of death due to food borne illness in the United States and Europe (Cook et al, 2000; Scallan et al, 2011). The disease is more dangerous for its IMH without shedding for clear diagnostic stages, in body excreta. Immunological diagnosis considered being the only available way for diagnosis of infection in these hosts (Habibi et al, 2012) for this reasons; iden- tification of easily applicable accurate diagnostic technique playing an important role in early diagnosis of infected animals. ELISA is considered as one of the best sensitive diagnostic techniques suitable for examination of large number of samples simultaneously (Gamble et al, 2005 and Liu et al, 2015).

Using of the milk other than serum as a tool for diagnosis have several benefits such as it easy to collect, store, obtained at low cost in sufficient quantities for analysis. In relation to quantity of milk, the antibodies levels in serum were higher than in milk (Farnaud et al, 2010; Malamud and Rodriguez-Chavez, 2011).

The present study aimed to standardizing an ELISA technique in diagnosis of toxoplasmosis in goats as compared with commercial Modified Agglutination Test (MAT) kits. Both were used to estimate the value of raw milk instead of serum for determination 
of infection in different breeds of the Egyptian goats.

\section{Materials and Methods}

All steps and procedures were approved by the Institutional Animal Care and use ethical Committee (IACUC), Faculty of Veterinary Medicine, Cairo University (Cu F Vet/F/ SUR/2013/16).

Study sites and investigated goats: This study was carried out from January to December 2015; in three governorates (Cairo, Giza and Qalyoubia) in Egypt. The study focused on investigation of goat flocks that reared by Nomadic. The flocks camp at night in special places as Maryottia in Giza, Al-Basatien region in Cairo and ElMarg City in El-Qalyoubia. Through monthly visit to these goat collections, the target animals were identified by ear tags. The animals were investigated from different aspects include general health conditions, stage of pregnancy, rate of successful pregnancy, number of offspring's per year, rate of repeat breeding, healthy condition of the udder and amount of daily milk yield.

A total of 600 female goats were examined. Blood samples were collected from Jugular vein; used after this for separation of serum. Milk samples were taken manually after disinfection of the teats with iodine alcohol and use of gloves during manipulation. Samples were collected in clean, dry \& sterile test tubes. Samples were kept under refrigeration during transfer to the Parasitology laboratory, Faculty of Veterinary Medicine. Samples were stored under freezing till needed. The frozen milk samples were thawed at room temperature, centrifuged at 3000rpm for 10 minutes. The clear fraction was examined for anti- $T$. gondii antibodies without dilution (Tavassoli et al, 2013).

$T$. gondii infected goats' sera: Sera of $35 T$. gondii aborted goats were used as reference for the serological tests used in the present study. These sera were collected from goats suffering from abortion and $T$. gondii tachyzoites were successfully detected in stained smear prepared from their aborted materials (Ragozo et al, 2009). Also, 50 negative sera collected from healthy goats were used as control.

ELISA: The test was performed (Lind $e t$ $a l, 1997)$ with some modifications. Optimal dilutions for ELISA were adjusted using checkerboard titrations for sera, antigen and conjugates. Polystyrene plates were coated with $100 \mu 1$ of antigen/well (soluble antigen extracted from laboratory prepared mice propagated $T$. gondii $\mathrm{RH}$ strain) $4 \mathrm{mg} / \mathrm{ml}$ in coating buffer, and then incubated overnight at $4^{\circ} \mathrm{C}$. The plates were washed three times with PBS containing $0.01 \%$ Tween 80 (PBSTween), and blocked for $0.5 \mathrm{~h}$ at $37^{\circ} \mathrm{C}$ with carbonate buffer ( $\mathrm{pH}$ 9.6) containing $10 \%$ BSA in a humid chamber. After 3 times wash, $100 \mu$ of serum sample diluted 1:100 in PBS was added and the plate was incubated for $1 \mathrm{~h}$ at $37^{\circ} \mathrm{C}$. After washing as above, $100 \mu \mathrm{l}$ of HRP (Horse-Radish Peroxidase)-Protein A conjugate (Sigma-Aldrich) diluted 1:2,000 in blocking buffer was added to the wells and incubated at $37^{\circ} \mathrm{C}$ for an hr. After washing, $100 \mu \mathrm{l}$ of substrate $(0.4 \mathrm{mg}$ / $\mathrm{mL}$ of o-phenylenediamine, $0.0125 \%$ hydrogen peroxide in $0.1 \mathrm{M}$ sodium citrate buffer, $\mathrm{pH}$ 5.0) was added and the plate was left for $10 \mathrm{~min}$ at room temperature. The reaction was stopped with $100 \mu \mathrm{l}$ per well of $0.5 \mathrm{M}$ sulphuric acid and Optical Density (O.D.) at $490 \mathrm{~nm}$ was read in a micro plate reader (full automated Titreteck multiskan ELISA reader). All samples were run in duplicate. Each plate contained 3 positive and 2 negative reference serum samples. The samples were considered positive when its O.D. was equal or over to double fold of mean negative O.D. control sera.

Modified Agglutination Test (MAT): Test was performed using commercial kit ToxoScreen DA (Bio-Mérieux, France) accordingly to manufacturer's instructions and Sroka et al. (2008). The test was used for the detection of Toxoplasma $\mathrm{IgG}$ antibodies in serum and milk by direct agglutination using a sensitised antigen. IgM-mediated agglutination was supperssed by using a diluting 
buffer containing 2-mercaptoethanol. The test was performed using microtitre plates with U-shaped wells. In the screening procedures, control and diagnostic sera were used as 1:1, 1:10, 1:25, 1:100 \& 1:400. A positive reaction exhibits agglutination of the Toxoplasma in a MAT covering about half of the well base. In the absence of specific antibodies, a solid button is obtained. According to the test instruction, a titer of 1:25 was considered positive and a titer of 1:10 was considered suspect. Milk samples were screened using California Mastitis Test (CMT) after Shearer and Harris (2003) to detect different subclinical mastitis degrees.

Statistical analysis: Differences of infected goats between breeds, ages and locality were analyzed using the SPSS V.11. Differences between factors were considered significant when $(P<0.05)$.

\section{Results}

There was high sensitivity and specificity for ELISA (85\% \& 92\%) than that obtained after screening of the same samples using MAT $(80 \%$ \& $90 \%)$ respectively. There is a direct relationship between the mean ELISA O.D. value and the level of Abtiter in MAT positive sera.

ELISA and MAT were further adopted to investigate 600 serum and milk samples randomly collected from suspected flocks of grazing goats in 3 governorate of Egypt. Data (Tab. 3) revealed that infection by toxoplasmosis in the examined goats during complete one year reached to $22 \%$ and $20 \%$ after examination of these goats sera using ELISA \& MAT respectively. Screening of the milk collected from these animals revealed little lower \% reached to $20 \%$ and $18 \%$ using ELISA and MAT respectively. ELISA still proved to be more specific $(97.91 \%)$ and sensitive $(89.5 \%)$ in detecting the anti-Toxoplasma antibodies than MAT (97.3\% \& $88 \%$ respectively) after sera examination and it was also high for ELISA (as sensitivity was $88.7 \%$ \& specificity was $97.42 \%$ ) after examination of milk, while it was $86.36 \%$ and $96.94 \%$ respectively using MAT. Also, the prevalence recorded after ELISA was higher than that recorded using MAT and still high for serum than milk.

T. gondii $\operatorname{IgG}$ anti-bodies in serum and milk of goats using ELISA were given (Plate $1)$, ATAb was diagnosed in the examined goats sera by high rate (20 animal infected) during January, February and March, then the infection decreased significantly in April $(10, P<0.05)$ followed by a non-significant decrease $(P>0.05)$ in May (9). The number of animals decreased in June (5 goats), July (5 animals) and August recorded 3 infections only. A non - significant increase in number of animals infected occurred in September (5) followed by a significant $(P<$ $0.05)$ increase in October (10), while in November and December $(10,15)$ a significant $(P<0.05)$ increase was observed during these months. Through examination of milk of the same animals, ATAb in milk was associated with the same level in serum during January-March, then it decrease to 5 only during April and to 2 animals in May. On the contrary with sera no ATAb could be diagnosed in the examined milk samples during June-September, while it appeared again in 5 animals during October, then in same number of animals $(10 \& 15)$ as serum during November and December.

There was a variable level of infection among the three breeds of goats using ELISA. Infection rate was high in the Egyptian Baladi breed (30\% in serum \& $27 \%$ in milk), while the Barki breed was the lowest one (13.33\% in serum and $12 \%$ in milk). High rate of infection $(30 \%$ in serum and $27 \%$ in milk) was in goats $>2$ years old, while no ATAb could be diagnosed in goats less than one year old. The overall prevalence of infection $(39.28 \%$ in serum \& $37.14 \%$ in milk) was recorded in Qalyoubia Governorate, while the lowest one $(11.25 \% \& 9.58 \%)$ was recorded in Giza Governorate. It was important to identify that serum is usually induce high rate of infection than milk. 
The highest rate of anti-Toxoplasma antibodies was associated with goats with history of abortion in both of serum and milk (38.33\% and $31.66 \%$ respectively) followed by animals of udder affection (30.9 \& $25.45 \%$ respectively), while the lowest one in healthy goats $(18.96 \% \& 17.94 \%$ respectively). Disease history was reflected directly on mean O.D. value of these infected animals. The high mean O.D. value was in goats' sera with history of abortion (1.019), followed by those suffered from different degrees of subclinical mastitis (0.800), while it was 0.753 in healthy goats sera. All O.D. values of milk were lower than that of serum for same group; $0.671,0.643 \& 0.622$ respectively.

Details are shown in tables $(1,2,3,4 \& 5)$, and figure (1).

Table 1: Accuracy of ELISA \& MAT in detecting anti-Toxoplasma antibodies in T. gondii infected and control sera.

\begin{tabular}{|c|c|c|c|c|c|c|c|c|}
\hline \multirow{3}{*}{$\begin{array}{l}\text { Test } \\
\text { Sample }\end{array}$} & \multicolumn{2}{|c|}{ ELISA } & \multicolumn{6}{|c|}{ MAT ( tested serum dilution ) } \\
\hline & \multirow{2}{*}{ +ve } & \multirow{2}{*}{ - ve } & - ve & Suspect & \multicolumn{3}{|c|}{+ ve } & Total +ve \\
\hline & & & $1: 1$ & $1: 10$ & $1: 25$ & $1: 100$ & $1: 400$ & \\
\hline $\begin{array}{l}\text { Microscopic } T \text {. gondii aborted } \\
(\mathrm{n}=35)\end{array}$ & $\begin{array}{c}30 \\
85.7 \%\end{array}$ & $\begin{array}{c}5 \\
14.3 \% \\
\end{array}$ & $\begin{array}{c}2 \\
5.7 \%\end{array}$ & $\begin{array}{c}5 \\
14.3 \%\end{array}$ & $\begin{array}{c}16 \\
45.7 \%\end{array}$ & $\begin{array}{c}9 \\
25.7 \%\end{array}$ & $\begin{array}{c}3 \\
8.57 \%\end{array}$ & $\begin{array}{c}28 \\
(80 \%)\end{array}$ \\
\hline Negative healthy goats $(n=50)$ & $\begin{array}{c}4 \\
8.0 \% \\
\end{array}$ & $\begin{array}{c}46 \\
92.0 \% \\
\end{array}$ & $\begin{array}{c}44 \\
88 \% \\
\end{array}$ & $\begin{array}{c}6 \\
12 \% \\
\end{array}$ & 0 & 0 & 0 & $\begin{array}{c}44 \\
(88 \%)\end{array}$ \\
\hline
\end{tabular}

Table 2: Relation between ELISA O.D. \& MAT titer.

\begin{tabular}{|l|c|c|}
\hline Factors & ELISA & MAT \\
\hline Sensitivity & $85 \%$ & $80 \%$ \\
\hline Specificity & $92 \%$ & $90 \%$ \\
\hline Predictive value +ve & $88 \%$ & $84 \%$ \\
\hline Predictive value -ve & $90 \%$ & $86 \%$ \\
\hline Prevalence & $41.18 \%$ & $41.18 \%$ \\
\hline
\end{tabular}

Table 3: Value of MAT and ELISA in detecting anti-Toxoplasma antibodies in milk and sera of goats.

\begin{tabular}{|l|c|c|c|c|}
\hline Factors & \multicolumn{2}{|c|}{ MAT } & \multicolumn{2}{c|}{ ELISA } \\
\hline Material & Milk & Serum & Milk & Serum \\
\hline Prevalence & $18 \%$ & $20 \%$ & $20 \%$ & $22 \%$ \\
\hline True positive & 95 & 110 & 110 & 120 \\
\hline False positive & 15 & 10 & 10 & 12 \\
\hline False negative & 15 & 15 & 14 & 14 \\
\hline True negative & 475 & 465 & 466 & 454 \\
\hline Positive predictive value & 86.3 & 91.6 & 91.6 & 92.3 \\
\hline Negative predictive value & 96.1 & 96.88 & 97 & 97 \\
\hline Sensitivity & 86.36 & 88 & 88.7 & 89.5 \\
\hline Specificity & 96.94 & 97.3 & 97.42 & 97.91 \\
\hline 95\% CI & $0.18,0.86$ & $0.20,0.916$ & $0.20,0.91$ & $0.22,0.90$ \\
\hline
\end{tabular}

Table 4: Effect of breed, age and locality on toxoplasmosis ELISA level in goats' milk and sera.

\begin{tabular}{|c|c|c|c|c|c|c|}
\hline \multirow{2}{*}{ Factor } & \multirow{2}{*}{ Category } & \multirow{2}{*}{$\begin{array}{c}\text { No. } \\
\text { examined }\end{array}$} & \multicolumn{2}{|c|}{ Number positive (\%) } & \multicolumn{2}{|c|}{$P$ value } \\
\hline & & & $\mathrm{S}^{*}$ & $\mathrm{M}^{* *}$ & $\mathrm{~S}$ & $\mathrm{M}$ \\
\hline \multirow{3}{*}{ Breed } & Egyptian Baladi & 200 & $60(30.00)$ & $54(27.0)$ & 0.013 & 0.011 \\
\hline & Barki & 150 & $20(13.33)$ & $18(12.0)$ & 0.017 & 0.015 \\
\hline & Zaraibi & 250 & $52(20.80)$ & $48(19.2)$ & 0.02 & 0.02 \\
\hline \multirow{3}{*}{ Age } & $<1$ year & 80 & 0 & 0.00 & 0.0 & 0.0 \\
\hline & $1-2$ year & 220 & $42(19.0)$ & $39(17.7)$ & 0.042 & 0.032 \\
\hline & $>2$ year & 300 & $90(30)$ & $81(27)$ & 0.012 & 0.010 \\
\hline \multirow{3}{*}{ Locality } & Cairo & 220 & $50(22.72)$ & $45(20.45)$ & 0.023 & 0.025 \\
\hline & Giza & 240 & $27(11.25)$ & $23(9.58)$ & 0.041 & 0.030 \\
\hline & ElKaliobeya & 140 & $55(39.28)$ & $52(37.14)$ & 0.020 & 0.019 \\
\hline
\end{tabular}

\footnotetext{
$* \mathrm{~S}=$ Serum samples, $* * \mathrm{M}=$ Milk samples
} 
Table 5: Relation between anti-Toxoplasma antibodies in serum \& milk and diseases history of goats by ELISA

\begin{tabular}{|c|c|c|c|c|c|c|}
\hline History of goats & & No. examined & No.+ve & $\%$ & O.D. range & Mean O.D. \\
\hline \multirow{2}{*}{$\begin{array}{l}\text { Affected udder (sub } \\
\text { clinical mastitis milk) }\end{array}$} & $S$ & \multirow{2}{*}{55} & 17 & 30.9 & $0.491-1.044$ & 0.800 \\
\hline & $\mathrm{M}$ & & 14 & 25.45 & 0.434-0.909 & 0.643 \\
\hline \multirow{2}{*}{ History of abortion } & $\mathrm{S}$ & \multirow[b]{2}{*}{60} & 23 & 38.33 & $0.981-1.244$ & 1.019 \\
\hline & $\mathrm{M}$ & & 19 & 31.66 & $0.687-0.876$ & 0.671 \\
\hline \multirow{2}{*}{ Healthy } & $\mathrm{S}$ & \multirow{2}{*}{485} & 92 & 18.96 & $0.499-0.865$ & 0.753 \\
\hline & $\mathrm{M}$ & & 87 & 17.94 & $0.411-0.789$ & 0.622 \\
\hline \multirow{2}{*}{ Total } & $\mathrm{S}$ & \multirow{2}{*}{600} & 132 & 22.00 & $0.491-1.244$ & 0.899 \\
\hline & $\mathrm{M}$ & & 120 & 20.00 & $0.411-0.909$ & 0.645 \\
\hline
\end{tabular}

\section{Discussion}

Toxoplasmosis plays an important role as zoonotic parasites from cats to any animals and human in rural areas specially that use un-pasteurized milk. Contamination of milk with $T$. gondii oocysts originated from the infected cat's faeces from stray cats that found around and within milk production area. Moreover; T. gondii oocysts shed continuously in infected cat's faeces from 4 to 14 days after infection with peak output of about millions oocysts at 6 to 8 days (Sadek et al, 2015). As no special goat farms in Egypt, the main collections of goats are available as grazing flocks that reared by nomadic. These flocks move through the cities toward its periphery searching for green food along the year. They usually accompanied with stray dogs \& cats during travelling and contact to them during camping. The owners of these animals are very primitive people, drink milk of these goats and collect it sending to cheese manufactures directly. These animals did not exposed to any veterinary services including examination and treatment. Owners of these flocks improving them using the culling methods than treatment as they continuously exclude the non-productive animals.

As infected living animal did not shed accurate diagnostic stage, the present study was started by determination to sensitivity, specificity and predictive value of modified ELISA in comparison with MAT using serum samples collected from Toxoplasma aborted and control goats. Toxoplasma tachyzoites were isolated from the aborted materials of this infected group and identified microscopically in stained smears. After serological examination to sera of the previous groups, ELISA proved to be more specific and sensitive (92\% \& 85\%) than MAT $(90 \% \& 80 \%)$. Moreover, there was a direct relationship between the mean ELISA O.D. value and the level of anti-Toxoplasma antibodies in MAT positive sera, which agreed with Dubey et al. (1995); Gamble et al. (2005) and Sroka et al. (2008).

As collection of blood samples and separation of serum still need some precautions as well as specific equipment, so successful using of milk as a clinical tool, for diagnosis of anti-parasite antibodies or antigen has many advantages over serum. This fluid is usually easy to collect, store, cheap and it can be obtained at low cost in sufficient quantities for analysis. The milk is easier to handle for diagnostic procedures after centrifugation, since it does not clot; more accessible, less expensive and less risk (Farnaud et al, 2010).

After examination of goats flocks in the 3 governorates over a year, the overall all prevalence reached up to $22 \%$ and $20 \%$ by sera examination by ELISA \& MAT respectively. This prevalence was higher than $10.48 \%$ reported by Sadek et al. (2015), but also, lower than 58.9\% reported by Abdel-Rahman et al. (2012). The differences in results might be attributed to the diagnostic technique used, study locality, breeding conditions and/or management.

The present study evaluated milk as a sample material for diagnosing toxoplasmosis in goats. Screening of the milk collected from them showed somewhat little lower values (20\% \& 18\%) when using ELISA and MAT respectively. The result agreed with 
Dehkordi et al. (2013) as prevalence in milk was lower $(8.88 \%)$ than that recorded by serum examination by ELISA. This showed that milk could be used as a sample for toxoplasmosis diagnosis. Malamud and Rodriguez-Chavez (2011) mentioned that body fluids such as saliva or milk were used for diagnosing many parasitic diseases, but levels of antibodies were higher in serum than in other body fluids.

The anti-Toxoplasma antibodies in serum and/or milk were diagnosed by ELISA and MAT. ELISA proved to be more sensitivity $(88.7 \%)$ and more specific $(97.42 \%)$ than MAT (86.36\%; 96.94\% respectively), which agreed with Dubey et al. (1995).

Serum antibodies recorded in an endemic area indicated past or present invasive disease, while presence of antibodies in milk indicate present of active infection that reflected local antigenic stimuli to infection and helped in disease epidemiology studies (Grundy et al, 1983). Anti-Toxoplasma antibodies were recorded along the year in sera of infected animal, it was high during January, February and March, decreased during April to May, then increased again from October to December. Through examination of milk of the same animals, anti-Toxoplasma antibodies in milk were associated with the same level in serum during January-March and then decreased during April to May. On the contrary with sera no antibodies could be diagnosed in the examined milk samples during June-September, which agreed with the explanation given by Abdel-Rahman et al. (2012) who found T. gondii tachyzoites in the milk of both chronically and acutely infected goats. They explained the presence of $T$. gondii antibodies in the milk of chronically infected goats was due to the resurgence of tissue $T$. gondii tachyzoites cysts, which can circulate again and be excreted in the milk during physiological decrease in the peripartum immunity thus; explain the nature of appearance of antibodies during the year.

Seroprevalence in goats increased progres- sively in goats increased progressively with age (1-2 year) was $19 \%$, while $\geq 2$ year was $30 \%$. The high overall prevalence $(39.28 \%$ in serum $\& 37.14 \%$ in milk) was recorded in Qalyoubia Governorate, but lowest $(11.25 \%$ $\& 9.58 \%$ ) was recorded in Giza Governorate. The prevalence was high in Egyptian Baladi breed $(30 \%$ in serum and $27 \%$ in milk), while the Barki breed was the lowest one (13.33\% in serum and $12 \%$ in milk). This might be due to the difference in grazing type, climatic condition, susceptibility of breeds present, ecological conditions, husbandry practice, the numbers of cats and rodents present as well as difference in the level of control measures applied. As old animals has more chances for contact and exposed to infected cat's faeces, high rate of infection (30\% in serum \& $27 \%$ in milk) was recorded in goats $>2$ years old, while no antibodies were diagnosed in goats less than one year old. This was agreed with Masala et al. (2003) who mentioned that the detection of antibodies along the year indicated continuous exposure of goats to infection due to heavy environmental contamination with oocysts shed form the stray cats especially with poor sanitary conditions. Besides, the highest rate of antibodies in serum and milk was among goats with history of abortion, followed by animals of udder affection. The high mean O.D. value was recorded in sera of goats with history of abortion followed by those suffered from different degrees of subclinical mastitis. In all O.D. values of milk were lower than that of serum.

In Egypt, Haridy et al. (2010) in Egypt studied the seroprevalence of $T$. gondii in draught horses (3-15 years) including 90 males and 10 females and found overall ELISA- $T$. gondii antibodies were $25 \%$ of the horses in Greater Cairo, $50 \%$ (females) and $22.2 \%$ (males). Haridy et al. (2010) examined donkeys (75 females \& 25 males) aged between 3-10 years, and found that ELISA antibodies of $T$. gondii were in $45 / 100$ (45\%) working donkeys. Donkeys' milk was T. gondii positive in $7 / 15(46.3 \%)$ pregnant 
females. Dubey et al. (2014) infected eight goats with 300 to 10,000 oocysts of $T$. gondii strain TgGoat-US26. They found that $T$. gondii was excreted in goat's milk and can survive in fresh cheese made by coldenzyme treatment. They concluded that to prevent zoonosis transmission, milk should not be consumed raw as well as raw fresh goat cheese made by cold-enzyme treatment of unpasteurized milk.

Saleh et al. (2014) in Alexandria reported anti-Toxoplasma antibodies in hospitalized pregnant women and child-bearing women. They recommended that health education should be tailored to women of childbearing age to prevent its complications and periodic examination for people who continuously contact with cats and immunosuppressed patients. They added that the hospital staff should put a policy of systematic procedure for recording, reporting, analyzing, investigation of toxoplasmosis, and the intervention of nurses to achieve the successful improvement in their knowledge, attitude, and control measures compliance. Also, the Livestocks' management, their meat and milk products influence the zoonotic risk of toxoplasmosis. Saleh et al. (2016) reported that toxoplasmosis must be considered an occupational, nosocomial and/or the hospital acquired infection.

\section{Conclusion}

Milk rather than serum can be used for diagnosis of toxoplasmosis in goats. ELISA was more specific and sensitive than MAT in antibodies detection in serum and milk. The titter was lower in milk than serum, but more related to active infection.

Infection was high in older goats of Egyptian Baladi breed than young one in ElQalyoubia Governorate. Integrated control strategies and measures are recommended to minimize $T$. gondii infection in goats. The animals must be routinely investigated, prevent the arrival of wild carnivore and rodents to goats dwelling, improve the personal hygiene knowledge's of shepherds, boiling or pasteurization of milk before con- sumption or manufacturing. Consumption of unpasteurized goat cheese and/or milk could be a risk factor for zoonotic toxoplasmosis.

Conflict of Interest: The authors have neither conflict of interest nor received grant.

\section{References}

Abdel-Rahman, MAM, EL-Manyawe, SM, Khateib, AM, Saba, S, 2012: Occurrence of Toxoplasma antibodies in caprine milk and serum in Egypt, Assiut Vet. Med. J. 58, 133:14552.

Cook, AJ, Gilbert, RE, Buffolano, W, Zufferey, J, Petersen, E, et al, 2000: Sources of Toxoplasma infection in pregnant women: European multicentre case-control study, European Research Net-work on Congenital Toxoplasmosis. Brit. Med. J. 321:142-7.

Dehkordi, FS, Rahimi, E, Abdizadeh, R, 2013: Detection of Toxoplasma gondii in raw caprine, ovine, buffalo, bovine, and camel milk using cell cultivation, cat bioassay, capture ELISA and PCR methods in Iran. Foodborne Path. Dis. 10, 2:120-5.

Dubey, JP, 2010: Review of toxoplasmosis of animals and humans. Parasite Vectors 3:112-9.

Dubey, JP, Jones, JL, 2014: Comment on detection of Toxoplasma gondii in raw caprine, ovine, bovine, and camel milk using cell cultivation, cat bioassay, capture ELISA \& PCR methods in Iran. Foodborne Path. Dis. 11, 6:500-1.

Dubey, JP, Thulliez, PH, Weigel, RM, Andrews, CD, Lind, $P$, et al, 1995: Sensitivity and specificity of various serologic tests for the detection of Toxoplasma gondii infection in naturally infected sows. Am. J. Vet. Res. 56:1030-6.

Dubey, JP, Verma, SK, Ferreira, LR, Oliveira, S, Cassinelli, AB, et al, 2014: Detection and survival of Toxoplasma gondii in milk and cheese from experimentally infected goats. J. Food Prot. 77, 10:1747-53.

Masala, G, Porcu, R, Madau, L, Tanda, A, Ibba, B, et al, 2003: Survey of ovine and caprine toxoplasmosis by IFAT and PCR assays in Sardinia, Italy. Vet. Parasitol. 117:15-21.

Farnaud, SJ, Kosti, O, Getting1, SJ, Renshaw, D, 2010: Saliva: Physiology and Diagnostic Potential in Health and Disease. Sci. World J. 10: 434-56.

Gamble, HR, Dubey, JP, Lambillotte, DN, 2005: Comparison of a commercial ELISA with the modified agglutination test for detection of Toxoplasma infection in the domestic pig. Vet. 
Parasitol.128:177-81.

Grundy, MS, Cartwright-Taylor, L, Lundin, L, Thors, C, Huldt, G, 1983: Antibodies against Entamoeba histolytica in human milk and serum in Kenya. J. Clin. Microbiol. 17, 5:753-8. Habibi, GR, Imani, AR, Gholami, MR, Hablolvarid, MH, Behroozikhah, AM, et al, 2012: Detection and identification of Toxoplasma gondii type one infection in sheep aborted fetuses in Qazvin province of Iran. Iran J. Parasitol. 7, 3: 64-72.

Haridy, FM, Saleh, NM, Khalil, HH, Morsy, TA, 2010: Anti-Toxoplasma gondii antibodies in working donkeys and donkey's milk in greater Cairo, Egypt. J. Egypt. Soc. Parasitol. 40, 2:45964.

Haridy, FM, Shoukry, NM, Hassan, AA, Morsy, TA, 2009: ELISA-seroprevalence of Toxoplasma gondii in draught horses in Greater Cairo, Egypt. J. Egypt. Soc. Parasitol. 39, 3:821-6.

Lind, P, Haugegaard, J, Wingstrand, A, Henriksen, S, 1997: The time course of the specific antibody response by various ELISA in pigs experimentally infected with Toxoplasma gondii, Vet. Parasitol. 71, 1:1-15.

Liu, Q, Wang, ZD, Huang, SY, Zhu, XQ, 2015: Diagnosis of toxoplasmosis and typing of Toxoplasma gondii, Parasit. Vectors 8:292-306.

Malamud, D, Rodriguez-Chavez, IR, 2011: Sa liva as a diagnostic fluid. Dent. Clin. North Am. 55, 1:159-78.

Ragozo, MA, Yai, LEO, Oliveira, LN, Dias, R A, Goncalves, HC, et al, 2009: Isolation of To- xoplasma gondii from goats from Brazil. J. Parasitol. 95, 2:323-6.

Sadek, OA, Zeinab, MA, Huda, MA, 2015: Molecular detection of Toxoplasma gondii DNA in raw goat and sheep milk with discussion of its public health importance in Assiut Governorate. Assiut Vet. Med. J. 61, 145:166-77.

Saleh, AMA, Ali, HA, Ahmed, SAM, Hosny, S M, Morsy, TA, 2014: Screening of Toxoplasma gondii infection among childbearing age females and assessment of nurses' role in prevention and control of toxoplasmosis. J. Egypt. Soc. Parasitol. 44, 2:329-42.

Saleh, AMA, Al-Agroudi, MA, Morsy, TA, 2016: Occupational, nosocomial or hospital acquired toxoplasmosis. J. Egypt. Soc. Parasitol. 46, 3:407-18.

Scallan, E, Hoekstra, R, Angulo, F, Tauxe, R, Widdowson, M, et al, 2011: Foodborne illness acquired in the United States--major pathogens. Emerg. Infect. Dis. J. 17, 1:7-15.

Shearer, JK, Harris, JB, 2003: Mastitis in the dairy goats. IFAS Extension; Florida University, USA.

Sroka, J, Cencek, T, Ziomko, I, Karamon, J, Zwolinski, J, 2008: Preliminary assessment of ELISA, MAT, and LAT for detecting Toxoplasma gondii antibodies in pigs. Bull. Vet. Inst. Pulawy 52:545-9.

Tavassoli, M, Ghorban, ZM, Esmaeilnejad, B, 2013: Full detection of Toxoplasma gondii in sheep and goats blood samples by PCR-RFLP in Urmia. Vet. Res. Forum 4, 1:43-7.

Fig. 1: Monthly prevalence of $T$. gondii IgG antibodies levels in sera and milk of goats using ELISA.

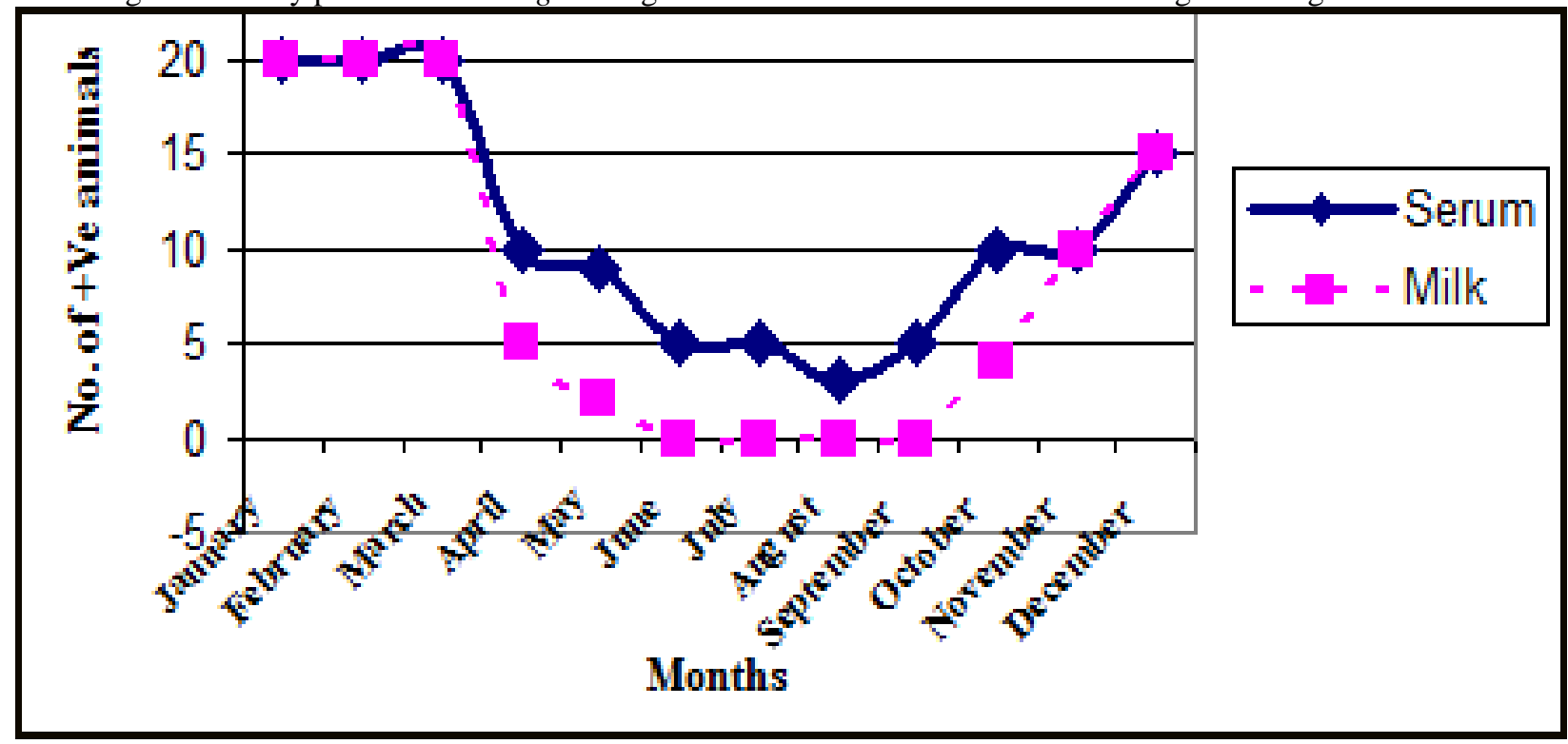

